\title{
NEW QUICHEAN CHRONICLES FROM HIGHLAND GUATEMALA
}

Robert M. Carmack

SUNY Albany, July, 1979

\section{INTRODUCTION}

\section{Quichean Ethnohistory}

Ethnohistoric studies of the prehispanic Quichean cultures of highland Guatemala (especially the Quiche, Cakchiquel, and Tzutujil groups) have primarily been focused on native chronicles written during the middle of the 16th century. In addition to the justifiably famous Popol Vuh and Annals of the Cakchiquels, there are another 16 major and 10 minor documents of this type. The $P V$ and Annals are easily the most extensive of these and provide us with the "official" view of Quichean history and culture. The other native documents are crucial for a well rounded reconstruction, because they provide us with insights into the variation on Quichean culture and history which existed. Consequently, most of my efforts and those of other scholars of Quichean cultures have been put into the discovery, transcription, translation, and exegesis of the native chronicles.

There are, of course, other kinds of important documentation of the Quichean cultures. We have the brief but important eye witness accounts by the conquistadores; a few fairly extensive relaciones by Spanish officials and priests; administrative records of all kinds, many of which are located in the archives in Spain; a very substantial corpus of native language dictionaries; and a half-dozen or so important creole histories from the centuries following the Conquest.

The relative ethnohistoric potential of Quichean culture in Mesoamerican studies is difficult to evaluate. On the one hand, it falls short of other Mesoamerican cultures and subareas. For exampl?, Alvarado's account of the conquest of Guatemala cannet compare with Cortez' magnificent letters on the conquest of Mexico. Las Casas' 
relación does not equal Landa's description of Yucatan. The censuses from Guatemala are later and much less detailed than those incredible records from Mexico. Fuentes y Guzmán was far from being a Torquemada. The painted codices from central Mexico, Oaxaca, and Yucatan are entirely lacking for the Quichean area. On the other hand, in terms of native chronicles and dictionaries the Quichean sources may be equal to or better than any other area in Mesoamerica.

The Quichean area is also a fruitful field for archaeological and ethnographic research. Few cultures in Mesoamerica have left as many well preserved archaeological sites as the Quichean. Mixtec culture is probably its closest rival. In recent years. I have attempted to coordinate reconnaissance studies of Quichean archaeology. With the aid of the documents, we have located numerous major new sites, and have explored in detail the settlement pattern in the region around the Quiche capital of Utatlan (Carmack, Fox, Stewart, 1975). John Fox (1978) has compared Quichean architecture and settlement patterns in an important study, and is able to work with a corpus of about 100 major sites. We feel that the opportunities for combining documentary with archaeological sources in the Quichean case compares favorably with anywhere else in Mesoamerica.

The situation is similar with respect to ethnographic studies of surviving Quichean cultures. Like the highlands of Chiapas, we have found prehispanic clan and ritual structures largely intact. Even though historical ethnography is somewhat out of vogue and is a slow and high skill-demanding task, we think the benefits from it for reconstructing Quichean cultures are well worth a major effort.

\section{The Discovery}

I mention our archaeological and ethnographic studies because it is in connection with that work that I made a documentary discovery of primary significance in the Summer of 1973. As part of our ethnological and archaeological survey that year, we went to Totonicapan. We were primarily interested in locating the prehispanic settlement of Totonicapan, which was unreported at that time. As I had visited the community many previous times in search of ancient documents, we were well received by the native officials, who gave us their full collaboration. With the help of a guide assigned to us, we located the prehispanic settlement, as I will describe below. More importantly, the indigenous alcalde was so excited about our work that he allowed me to do what I previously had been trying to do for 10 years: to 
personally examine the large stack of ancient titulos which they kept in the alcaldia. I was disappointed to find, however, that the original Titulo Totonicapán was not one of the documents in their possession, even though I had previously been told that it was. In fact, the only document which seemed to refer to the prehispanic cultures was the translation into Spanish of a tiny part of some document with which I was unacquainted. The document had been instigated as a land title by the parcialidad Yax, which I knew to be the most influential clan of the community.

It so happened that our guide was from the Yax parcialidad, and with his help, I was able to meet with the leaders of that group. I explained my interest in their history and culture, and showed them my book as an example of the kind of studies I made of ancient documents.

As we conversed in Quiche, I tried to communicate understanding of and interest in their clan organization. The approach worked, because they soon sent for the keeper of the documents, and in my presence opened a large box containing their sacred documents. Inside were several modern land titles and other legal documents, as well as a large, leather-bound, ancient book, written in the Quiche language.

It did not take long to realize the importance of this book. I saw immediately that it contained the original Quiche text of the Titulo Totonicapán, and other chronicles I had never seen before. As calmly as I could speak, for I was very excited, I asked permission to have the book copied. I offered several services in return: to make a typewritten copy of the documents and a translation of them into Spanish for their grandchildren; to provide them with their own photocopy of all the documents, which were disintegrating; to donate money to their clan.

They agreed, and together we marched to the photocopying machine in the town center. They personally cut the binding holding the book together, and handed over and received in turn each page as it was copied. Unfortunately, the machine was not a very good one; and the pages became more faded as time went on (to my great anguish). Finally after about 3 hours of photocopying the work was completed. I took them all to dinner, and we parted. Later, as I returned to my pension with the precious treasure, I remember how paranoic I felt about losing the copies. I have since returned to Totonicapan to take photographs of certain parts of the documents. and to check my transcriptions with the original texts. The Yax have 
remained friendly and cooperative, and I have visited them several times since 1973.

It is not my intent to analyze the process by which these documents were located, but to describe the documents and their meaning. Obvicusly, good fortune, as well as preparation and persistence went into the discovery process. Professionally, I recognize that their value is in the information they contain. However, there is great personal satisfaction in the process of discovery in ethnohistory, and I highly recommend it to others.

\section{List of Documents}

The old Yax book actually contained six different documents. Not surprisingly, one of the documents is a land title of the Yax clan it. self. I propose that it be called, Título Yax. The major document, the Titulo Totonicapan, is indeed the "mother document", as the natives refer to it. It is a land title for all the prehispanic groups who were brought together to form the colonial town of Totonicapan. Three of the documents were titulos for the Tamub branch of the Quiche at Totonicapan. Since one of them is the same document which I have elsewhere called Titulo Tamub, I shall refer to the other two as Tamub II and III. The sixth document was written by the Ilocab branch of the Quiche. Even though it is not a major statement about that group, I shall nevertheless refer to it as Titulo Ilocab, for we have no other título from that branch.

In the description of these documents that follows, the major discussion will be on the Quiche text of the Titulo Totonicapán. The other documents will be more briefly described.

\section{Título de Totonicapán}

The Título Totonicapán is well known to Mesoamerican scholars. It probably ranks third in importance, after the Popol Vuh and Annals of the Cakchiquels, among Quichean chronicles. Since roughly the middle of the 19th century, Padre Chonay's 1834 translation to Span. ish has been available to the scholarly world. Because of the importance of the document, and the fact that the opening pages of the original text were not translated by Chonay, many attempts have been made to locate the original. As I noted in my book (Carmack, 1973: 29), I too had searched for it in Totonicapan on several occasions, and had uncovered evidence that the original was still in existence. 
René Acuña, James Mondloch and I are in the process of translating and preparing a commentary on the entire Quiche text. The following comments are intended to suggest some of the most significant data which the Quiche text makes available to us. I have purposely paid more attention to the archaeological than the strictly ethnological implications.

\section{Biblical Section}

Of special interest, of course, is the first section of the text which was not translated by Chonay. He correctly stated that this part contains an account which is similar to that of the Old Testament, from the Creation to the Babilonian captivity. While it is true that this part of the narration follows the Bible much more closely than does the Popol $V u h$, it nevertheless diverges in subtle and interesting ways. I recommend it highly as one of the first attempts by native Guatemalans to syncretize their historical tradition with the Christian one.

One set of identifications made in that first section is of particular importance to Maya studies. We are specifically told in the Título Totonicapán that the twin heroes who descended to the underworld, Jun Ajpu and Xbalanquej, were equated by the Quiche with the sun and moon. This agrees with the account in the Popol Vuh (Recinos, 1953: 173), though Thompson (1970: 234) has questioned the accuracy of that great book on this point. He notes that Xbalanquej was the masculine sun deity for the Kekchi, and so probably would not have been identified with the feminine moon by the Quiche. The Titulo Totonicapán leaves us without any doubt on this point, for it states that Jun Ajpu, the sun, was a young man, while Xbalanquej, the moon, was a maiden. Apparently, the Quiche and their Kekchian neighbors held quite different beliefs with respect to Xbalanquej.

\section{Chonay Mistranslations}

The part of the Quiche text translated by Chonay has much additional information to offer us in terms of Quichean history and culture. A comparison of the non-biblical part of the text with Chonay's translation reveals that he made many errors in translation and transcription. There are also crucial omissions. The following are interesting examples of corrections we can make because of having thr original text. 
Chonay leaves out or mistranscribes several names mentioned in connection with the narration of the coming of the Quiche lords to the central Quiche area. One place, given as Chixpach in the text but mistranscribed as Chicpach by Chonay, can be identified as a canton in the municipality of San Andrés Sajcabaja. In fact, it is the territory in which the archaeological site of Patzak is located. This discovery is of special importance because personnel from the French archaeological mission, under the direction of Alain Ichon, have worked that site.

In another instance, Chonay leaves out the name of an important mountain, Mamaj, mentioned in connection with the entry of the Quiche lords into the highlands. Mamaj is identified by Quiche indigenes living to the northeast of present day Santa Gruz del Quiche as a twin-peaked mountain there. This landmark is given in some of the other chronicles, which, however, do not provide enough details to locate it for certain. The importance of Mamaj lies in the fact that it provides the key to locating the first Quiche capital, Jakawitz, an archaeological site which lies along the southern skirts of mount Mamaj.

Some names in the Totonicapan text which Chonay badly garbled have been the source of confusion for myself and other students of Quichean history. In one case, for example, he transcribed sic'a juanija as ciha tzununija, the latter two names being well known communities west of Lake Atitlan. Sic'ajanaja, "house of the tobacco or datura flower", was an important lineage of the Ilocab division of the tree Quiche confederates. The sic'a resided just west of Utatlan, far from Lake Atitlan. Another name, Tzutuja, "flowery water", was transcribed by Chonay as C"otuja, "sweatbath chief", the name of one of the most famous rulers of the Quiche kingdom. I postulated several years ago (Carmack, 1966) that C'otuja was adopted into the Quiche lineage system, later rising to the kingship. Tzutuja turns out to have no relationship to that king, but was an indigenous chief pressed by the Quiche into their military ranks.

I want to point out an omission by Chonay which has resulted in confusion about an important episode of Quiche history. It has to do with the fact that Chonay's translation does not mention the Quiche king, K'ucumatz, who in the Popol Vuh is said to succeed C'otuja, and preceed Quik'ab in the rulling Quiche line. Recinos (1950: 234, footnote 31) argues that the page telling about $K^{\prime}$ 'ucumatz must have been missing from the Titulo Totonicapán. Nicholson (1957: 261-262) and I (1968: 73-75) suggested that C'otuja and $K^{\prime} u c u m a t z$ might be titles of the same ruler. The Totonicapan text clarifies the 
matter. While Chonay did not leave out any page of the document, he did mistranslate the part of the royal genealogy having to do with C'otuja. Just as Nicholson and I had suspected, in the text the seventh ruler is referred to both as $C^{\prime} o t u j a$ and $K^{\prime} u c u m a t z$. His son, the 8th ruler, is also called $K^{\prime} u c u m a t z$, thus harmonizing the Totonicapan dynasty with that given in the Popol Vuh.

\section{The Pictorial}

One of the happiest surprises associated with finding the original text of the Titulo Totonicapán was the discovery of two pictorials in the text not mentioned by Chonay. One of the pictorials portrays the familiar two headed eagle, symbolic of the 16th century Spanish crown. The barely legible caption at the bottom of this heraldry reads, "Auto del Señor d Juan Aguilar, Conquistador". For the present, its significance will not be discussed. The other pictorial is of in. estimable value to Quichean scholars for artistic, ethnological, and archaeological reasons. I want to briefly discuss its ethnological and archaeological importance.

The pictorial portrays six buildings or structures, each identified with a brief caption (see figure 1). The inscription at the bottom of the drawing reads, "This is the stone and mortar (buildings) of the great Quiche in Utatlan, or as they say today, 'Santa Cruz" ". The four figures at the corners of the drawing are said to be the "buildings" of four lineages from Utatlan: the Q'uikab Ajpop Cawek, K'alel Nijaib, Nima Rajob Achij, and Ajaw Q'uiche. The rectangular building at the top center portion of the drawing is called the zoquibal, "the place of the obsidian hatchet". The central building is called the tzumpan, "the skull rack altar". Apparently, we have been provided with a 1554 schematic map of Utatlan, the Quiche capital.

The four lineage buildings probably represent the nim ja "big houses", frequently mentioned in the Quichean chronicles. They were administrative centers for the affairs of the lineages and for the kingdom ruled by the royal lineages. It is noteworthy that the four buildings vary in size according to the rank of the patron lineages. In contrast with Popol Vuh lineage ranking, however, the Totonicapan pictorial replaces the fourth ranked Saquic with the Nima Rajop Achij lineage. This is a significant alteration, for the Nima $R a$ job Achij was the militarized lineage of Tecum, the now immortalized Quiche "general" who resided in Totonicapan at the time of the conquest. The Titulo Totonicapán text also subsituted Tecum's line 

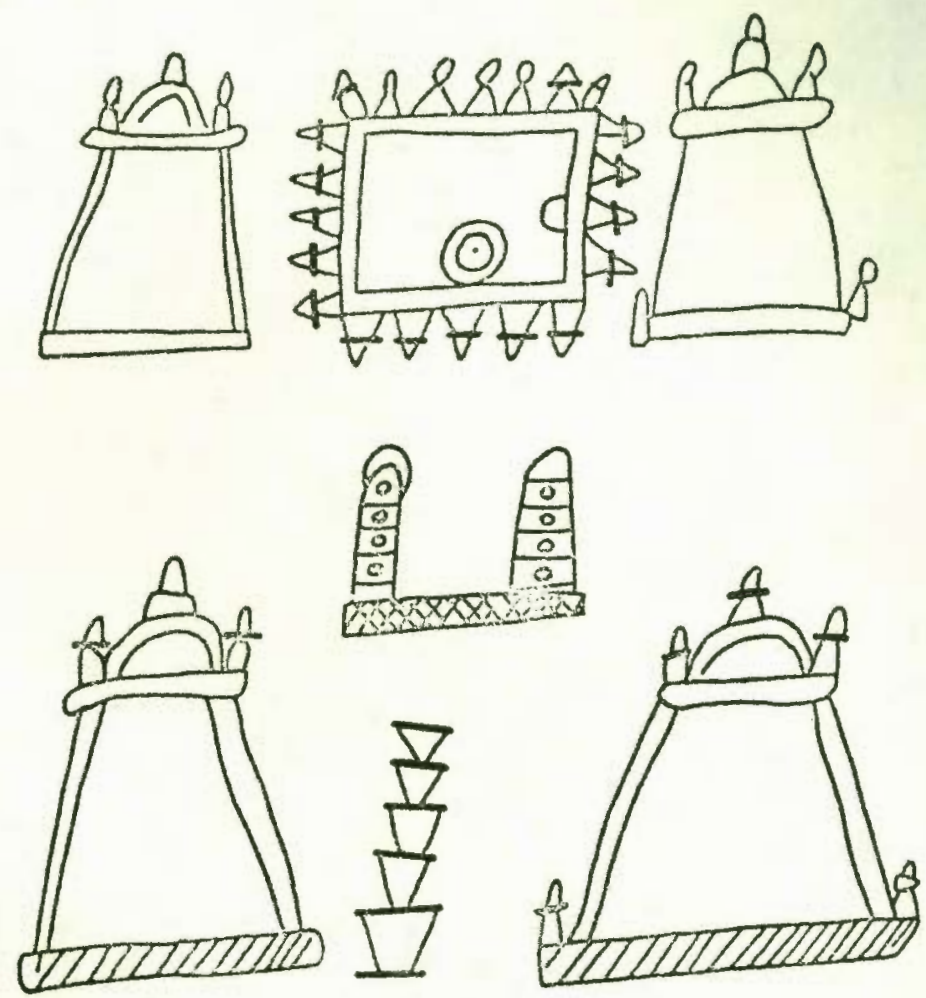

Figure 1

PICtorial of utatlan from totonicapan chronicle 
for that of the Saquic, and apparently rationalized this by explaining that the Saquic lineage was only an adopted line. This alteration suggests that there was interlineage competition for rank at Utatlan, and this must have been reflected in the size and number of lineage houses constructed there.

The zoquibal, "place of the obsidian hatchet", appears to have been a platform for gladiatorial sacrifice. Like its Aztec equivalent, the temalacatl, a round stone was placed on top of it. Prisoners were tied to the stone, while they battled warriors hafting obsidian-tipped weapons. Just as in the case of the Aztec gladiatorial platform, the Quiche zoquibal is placed near the skull rack.

The word tzumpan is an archaic nahuatl word meaning "skull rack altar". From the Aztec case we know that tzompantlis were low platforms upon which a structure for impaling skulls was built. They were placed in front of the major temples near the ball court. The Totonicapan drawing gives us our best evidence that the Quiche used the skull rack, though Las Casas (1958: 152) also seems to indicate that. Guillemin (1965) has suggested that an altar placed alongside one of the main temples of the Cakchiquel site of Iximche was a tzompantli. His suggestion is based on finding a painted mural on one side of the altar which shows skulls and crossbones, and a cache of decapitated skulls buried immediately behind the altar.

Can the Totonicapan drawing aid us in interpreting the settlement pattern of Utatlan? I think so, though the limited contents of the drawing mean that we will not be able to go far in this. Before looking at Utatlen settlement pattern, the perspective being portrayed by the Quiche artist must be clarified. We know from other pictorial art of the Quichean peoples that they expressed themselves within a variant of the Mixtec-Puebla style (Carmack and Larmer, 1971; Marquesee, 1974). This pictorial, however, has few of those characteristics. Apparently, the prehispanic artists were not at hand when the pictorial was produced. Nevertheless, the painter of the pictorial had probably at least seen indigenous murals and codices. He probably attempted to follow the native model in his drawing.

We might expect the lineage Big Houses to be shown in side view, so that in the case of the four buildings we apparently see only the roof, front and back walls, and the floor. Profile is frequently used for portraying administrative buildings in Mexican codices painted in the Mixtec-Puebla art style. The skull rack altar also appears to be in profile. We apparently see the ends of horizontally placed poles, upon which the skulls were impaled. In contrast with the lineage houses and skull rack altar, the gladiatorial platform is apparently 
presented to us in top view. Thus, we see adornments on all four sides of the platform, and the round stone on one side.

Figure 3 is a map indicating the main structures which have been located at Utatlan based on archaeological surface findings. It will be noted that the site consists of a main ceremonial precinct, and four flanking wings (west, north, east, and south). The ceremonial precinct is clearly the center of the site, and most likely the section to which the Título Totonicapán "map" refers. We find in the precinct a central temple mound facing another temple mound on the eastern side. Long, rectangular buildings flank the center on the northern and eastern sides, and part of the western side. The I-shaped ball court is south of the central temple, in the western zone of the center. $\mathrm{Nu}$ merous small platforms and altars, now only impressions on the cement floor, are located in the eastern zone of the center.

Comparisons with other Quichean sites lead us to believe that the "long structures", multi-entry buildings commonly found at Quichean sites, correspond to the lineage Big Houses of the documents. There are many long structures at Utatlan, but surely the Totonicapan drawing portrays only the most prominent ones asociated with the precinct center (see figure 2). As in the Titulo drawing, there are four large long structures located along the northern and eastern sides of the central court at Utatlan (structures 1, 2, 3, 4). There are several other possible identifications for the four buildings mentioned in the text, but the central court long structures are probably the best candidates. If this identification is correct, the northern structures (\#s 1 and 2) would correspond to the buildings of the Ajpop and Nina Rajop Achij lineages. These were both Cawek lineages, and their patron god Tlojil, "stormy", according to ancient tradition was housed in a temple adjacent to those two structures (i.e. structure 5). The two long structures flanking the temple to the east of Tojil (\# 3 and 4), would correspond to the Nijaib lineaje houses. The temple there (\#6) was probably the patron goddess of the Nijaib, called Awilix, "the moon" (?). The two sets of lineages apparently formed pantheistic oppositions of male-female, day-night, sun-moon, so that their locations at different sides of the court would symbolize a basic principle of Quiche cosmology.

According to the Totonicapan drawing, Utatlan's skull rack altar should be somewhere in the center of the main court. There are imprints left in the court's plaster of several small platforms and altars which might have been the skull rack altar (\#'s 7, 8). However, I think it more likely that it was located at the southeast corner of the temple of Tojil, toward the ball court (structure 9), as is 


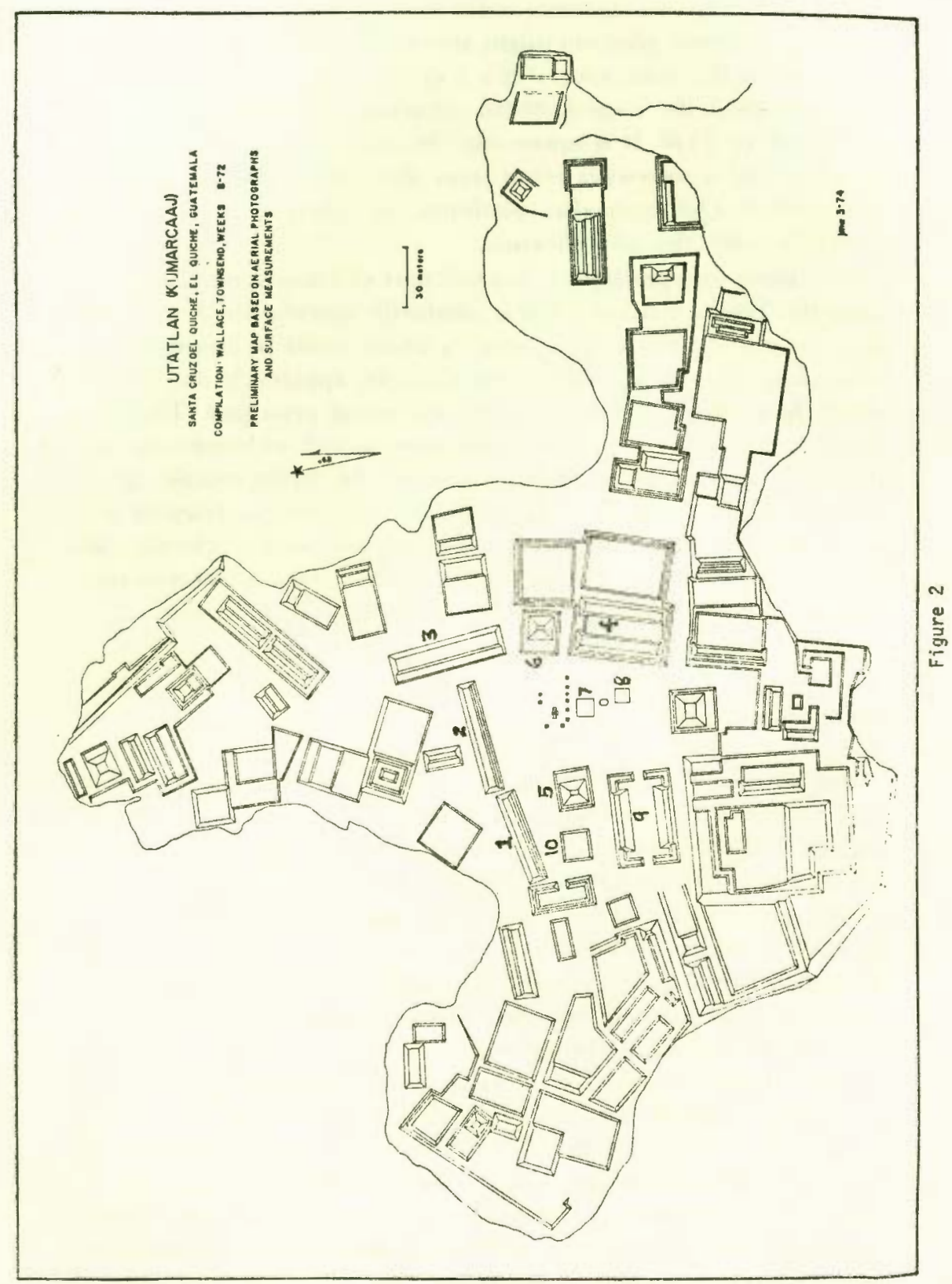


apparently the case at Iximche. Since there is a great deal of overfall at this place, only excavations could verify this suggestion.

The gladiatorial platform might also be one of the mentioned small structures in the main court (\#'s 7 or 8). Again, however, I think it is more likely the large platform (structure 10) located just behind the temple of Tojil. It is square like the zoquibal in the Totonicapan drawing, and is somewhat offset from the main court. Its large size compared to Quichean altar platforms, including the skull rack, is consistent with this identification.

The above interpretation of a small part of Utatlan archaeology by using the Totonicapan pictorial is admittedly speculative. Nevertheless it raises several interesting hypotheses which could be tested through excavating. The lineage houses, for example, apparently had benches along the back walls in order to seat the ruling principals. These can bc lccated in some of the long structures, as our archaeologists have verified in the case of the building south of the Awilix temple (\#4). The mural and cache of skulls found by Guillemin at Iximche hold out hope for a similar discovery at Utatlan and positive identification of the skull rack altar. The pictorial raises problems in interpretation, but they are problems which most archaeologists would welcome.

\section{Political Geography}

The Quichean chronicles were intended to serve as land titles, and the Titulo Totonicapán is no exception. The original Quiche text permits a much more accurate identification of ancient place and lineage names in the Totonicapan area than was previously possible. It will greatly expand our undestanding of the micro-political geography of the area, especially if the text is used in conjunction with information from native informants. Figure 3 illustrates some of the progress I have made in this regard, and should be used in conjunction with the following comments.

The chronicle provides an account of the incursion into the area of Quiche warriors, sent by the powerful king Q'uik'ab (c. 1450 A. D.). The warriors were rewarded for their military success with titles and jurisdictions. Accession to these honors took place, we are told, at joyam k'anak', "place of the hollow tree with broad leaves". Indigenes from Totonicapan claim that this place is in aldea Chimente, where many $k^{\prime} a n a k^{\prime}$ trees grow. They note that the leaves of this tree are used to wrap tamales. The chronicle also calls the place chay bamet, "obsidian stone, chewing tobacco", the latter word 


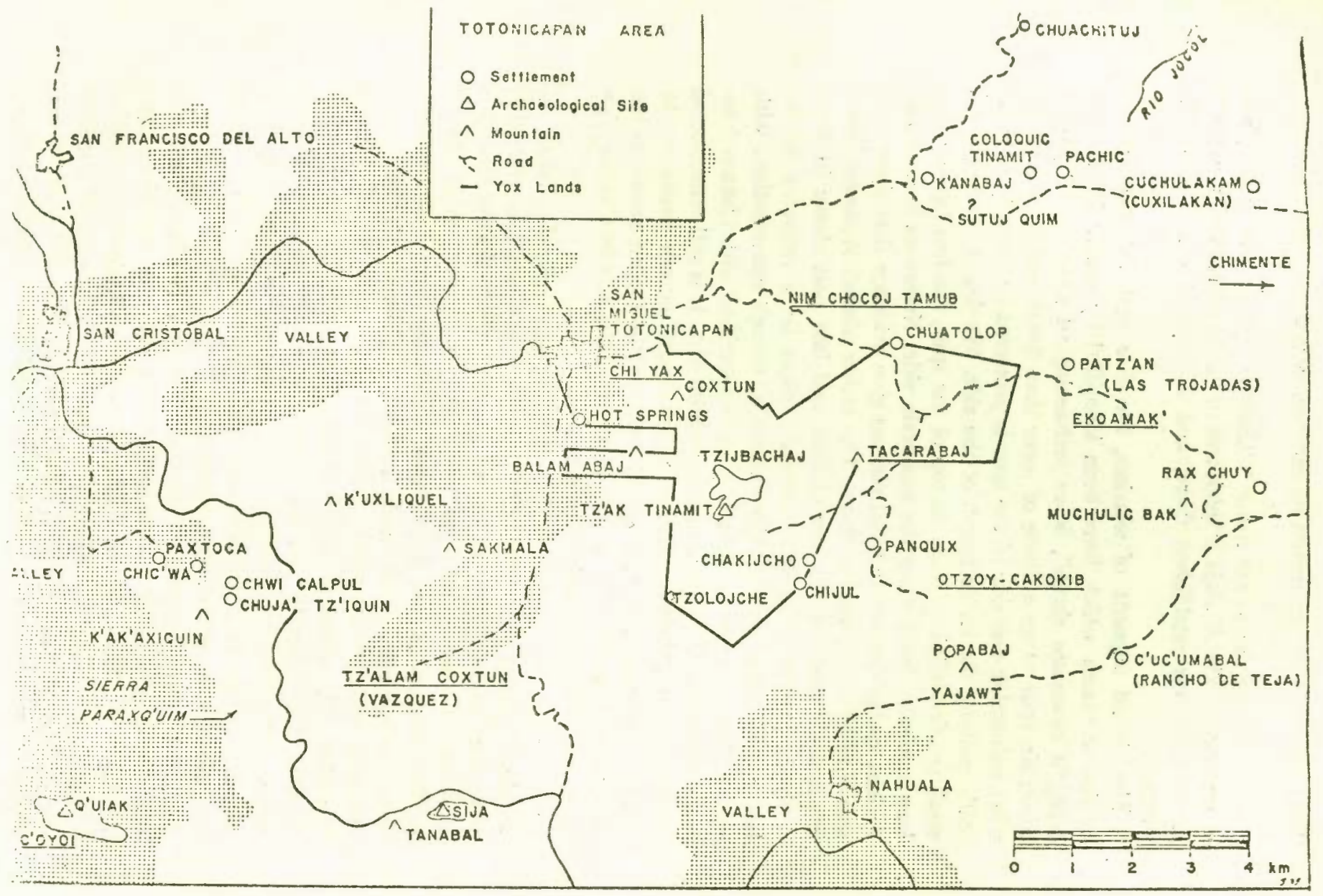

Figure 3

Estudios de Cultura Maya. Vol. XIII, 1981

Instituto de Investigaciones Filológicas/

Centro de Estudios Mayas, UNAM

http://www.iifilologicas.unam.mx/estculmaya/ 
probably giving rise to the name "Chimente" (from chi-, met, "place of tobacco"). The K'ulaja ("thick tree or mushroom house") segment of warriors was established there, and a fortified center was constructed.

The second segment of warriors, the Sija and Tz'alam coxtum, resided at places which have been identified by native informants. Sija, "a mountain shrub", is an archaeological site located atop a mountain spur at an altitude of more than 3000 meters. The somewhat vulnerable east side of the spur is protected by three huge stone walls running the entire length of the side. We found evidence of a small politico-religious plaza on top of the spur, reached by way of a long causeway leading up the mountain side. Numerous house foundations spread across the small plateau give evidence that there once was a resident population there. The rather abundant sherds prove conclusively that the site was Quiche and late post classic in time.

Tzalam coxtun, "walled fortress", might be a reference to the heavy fortification of the Sija mountain, though conversations with natives from the area suggest it is to be identified with Canton Vázquez, resting at the southern foot of mount Sija. It is still remembered as the ancient TŹalam. Based on a settlement pattern found nearby (to be discussed below), I would suggest that coxtun refers to fortifications along the edge of the great mountain axis in Canton Váz quez, called Paraxquim in the documents.

It is with the third warrior segment, the Tzijbachaj, that the Título Totonicapan is primarily concerned. We are told that they were the "leaders" (c'amol be ) of the area, and detailed boundary markers are given in order to delineate their territory. With the aid of Totonicapan natives, it has been possible to identify almost all of those ancient names with modern places. Tzijbachaj, "lighted torch", is a prominent plateau north of mount Sija, also over 3000 meters in elevation. The southwest finger of the plateau was identified as chitinamit, "the town"; i.e., the prehispanic and early posthispanic town of Chwi mik'ina (Totonicapan). Although we found some stone terraces and a small platform and earth mound, we failed to locate any substantial archaeological remains.

Further, there was no evidence of cut stone on the plateau, and very few sherds or obsidian artifacts. This was disappointing, since there can be no doubt that mount Tzijbachaj was the location of the original Totonicapan. The local inhabitants remember having found cut stone and old buried pots in the vicinity, so perhaps the 500 years of continuous posthispanic occupation has erased signs of the ancient set tlement. 
Incidentally, a sheep herder had been murdered on top the plateau about one week before our arrival, and the notoriety of that tragic event had brought the place into the consciousness of most of the inhabitants. It made our visit there sensitive.

A prominent mountain just north of Tzijbachaj is called coxtun, "fortress". It is located at the edge of the high mountain range overlooking the present-day town of Totonicapan. We found a flattened area there with cut stone and some low platforms, but only a few sherds. It is now an important shrine for modern priest-shamans. This place may have been a fortified point, providing the outer defense for Trijbachaj.

It is similar in pattern to Sija and its associated Tz'alam coxtun. These two sites, in fact, share many features, the most pronounced being their defensive positioning on extremely high mountain plateaus.

The Totonicapan chronicle informs us that five sons of the king himself settled in the Totonicapan area. The place of their residence is called Chuzvixtoca and Chic'wa, and is described as having buildings (see also Carmack, 1973: 359-61). With the help of native guides, we located Chic'wa in aldea Paxtoca, but again failed to find archaeological remains of the construction mentioned in the chronicle. Nevertheless, we obtained ethnographic information of considerable interest. Chic'wa "at the spring", still provides water for the people of Paxtoca. Above these springs is a place mentioned in the text as chuja' tz'iquin, "bird water on high". It is a beautiful waterfall which attracts many birds, who go there to drink. Huge outcroppings of prismatic stone form the wall of the waterfall.

Still higher up is a mountain called $k^{\prime} a k^{\prime} a x i q u i n$, "fire ears". It is believed that rumbling is heard at this mountain, caused by a lack of water inside the mountain; and this makes it hot dike fire. Along the northern side of the mountain are two large boulders, which to the natives look like ears. A much used altar placed underneath the boulders is called $t a$ 'bal $t z i j$, "place where "words are heard". Priestshamans $\left(a j k^{\prime} i j\right)$ petition the earth deity there because its ears can receive the message. The concept expresses an interesting totemic relationship between man, mountain, and animal (the ears).

\section{Other Títulos}

\section{Título Yax}

This document consists of 19 folios of text and two small pictorials. 
It appears to have been copied at some early date, for the signature of Juan de Rojas and Juan Cortés, the posthispanic caciques from Santa Cruz Quiche, on the last page are written in the same hand as the text. There is no date, and the land boundaries which one would expect to find accompanying a document of its kind are absent. I believe that the Spanish translation of the titulo which $I$ found among the documents in possession of the indigenous officials of the community was taken from the document under discussion. Like the Título $Y a x$, it has several references to the Nima Yax, "the great mature man". It consists almost solely of land boundaries, so may very well have been taken from the last pages of the Titulo Yax. Written in 1562 , it probably provides us with the date of composition of the Yax document. It should also be noted that this is apparently the " $t$ tubo antiguo" which García Elgueta (1962: 189-190) claims to have seen around the turn of the century.

Most of the Título $Y a_{x}$ text consists of an abbreviated version of the last section of the Popol Vuh. It follows the Ximénez text word for word in most places, beginning with the struggles between the Quiche at Jakawitz and their enemies, ending with the last succession of the Cawek rulers at Utatlan. Many portions of the Papol Vuh text are left out, while a few additions are inserted from place to place. One of the few single word alterations is the replacement of the Popol $V u h$ word for lineage, nim ja, with cumatzil "serpent". Presumably, that was the preferred term for lineage in the Totonicapan area.

Most of the additions to the Popol Vuh text seem to represent an attempt to tie the local rulers of Totonicapan to the Cawek dynastic line at Utatlan. We are repeatedly told that the Nima Yax, the ruler of Totonicapan, was the son of the Quiche king, Q'uik'ab. He is identified as the warrior sent to conquer the Mam (Zakulewab) in the Totonicapan area, an event described in more general terms in the Popol Vuh (Villacorta, 1934: 334). Besides the title, Nima Yax, the Totonicapan ruler also took his father's name ( $\left.Q^{\prime} u k^{\prime}{ }^{\prime} a b\right)$. Other names and titles by which he is referred are nebachij, topon, xinc'ar, xilla, and itzcot, "the first warrior", "the lancer", "the gatherer", "the respected (one)", and "eagle's collar (?)". The Nima Yax is also mentioned in Título Totonicapán as the chief lord of the prehispanic community.

The pictorial at the end of the Titulo Yax portrays a Quiche warrior with bow and arrow in hand, and shield to one side. He is standing on top of what appears to be a stone platform, to which is attached a banner. A speech scroll coming from his mouth suggests that he is speaking. Apparently the figure represents Nima Yax, the conqueror 
and ruler of Totonicapan. The art work is crude, and, as with the Título Totonicapán pictorial is not in Mixtec-Puebla style.

The Yax today claim that Nima Yax is their ancestor, and they are probably correct in this. The Yax are still the leading clan in Totonicapan, and are given the first seat in deliberations of the elders. Until 1934 they controlled the hot springs which today are the strongest symbol of the indigenous community's existence (Carmack, 1966). In a legal battle in 1945 with the other 48 parcialidades of the town, the Yax lost exclusive control of the hot springs. Nevertheless, they retain possession of San Miguel, the patron saint of the town.

The Spanish translation of what I believe to be the last part of the Titulo Yax clarifies that the Nima Yax resided in the prehispanic center located at Tzijbachaj. The land boundaries in that document, as well as those given in a more recent titulo in possession of the Yax, delineate a large territory for the Yax clan (see figure 3). It includes both the hot springs and the prehispanic settlement named after them, Chwi Mik'ina, "above the hot springs". Thus, the Titulo Yax explains to us why the Yax have been the guardians of Totonicapan's patrimony for the past five centuries.

\section{Tútulos Tamub}

The first of three land titles written on behalf of the Tamub branch of the Quiche at Totonicapan is word for word the same as the Titulo Tamub translated and published by Recinos (1957: 24.67). The only change is that additional boundary names are added to the list given in the Recinos version. We learn from this new version that it was originally written in the $1560^{\circ} \mathrm{s}$, almost 20 years before the Recinos copy.

The list of boundaries which corresponds to that given in the Recinos version demarcates the territory controlled by the Tamub from the central Quiche area. Such northeastern aldeas of modern Totonicapan as Pachoc and Chimente were included in the territory of the Tamub. The additional boundaries given in the Totonicapan version outline another Tamub territory south of there, extended from Patz'am to the border with Naguala. The Tamub moiety divisions were established there, the Ekoamak' around Patzam and the Kakokib near Panq'uix. The Kakokib area was named, Otzoy, "little mullusc", a name used to refer to the valley of Quetzaltenango and Totonicapan in general (Recinos, 1957: 71).

The second document, which I am referring to as Tamub II, also 
follows closely the text of the Título Tamub published by Recinos. It was written by Gristóbal Ramírez of Totonicapan in 1567. It is much briefer than the Titulo Tamul, leaving out most of the historical information of that document. The description of the Tamub clan structure is left intact, and the author's geneological cosnection with a second ranked lineage is revealed. Ramírez states that he was the son of the chief of the Nim Chocoj lineage in the Ekoamak' moiety, and that he represented the 11th succession within that line. $\mathrm{He}$ further claims to have held office in the presence of Tonati, Don Pedro de Alvarado, the conquistador. He includes a brief account of the conquest not contained in the Titulo Tamub, and also tells of the coming of the Spanish priests.

The boundary names given in the document indicate that this division of the Ekoamak' moiety resided in an area just northeast of the modern town center. They bordered with the Yax clan at the C'oxtun fortification.

The third Tamub document consists of 16 folios written by Pedro Velasco, a military official of the Tamub Quiche. It is apparently a sixteenth century copy of an undated titulo which was signed by principals from Totonicapan and surrounding communities. The contents of the Tamub III make it clear that they derive from three main sources: the Popol Vuh, Título Totonicaptán, and Título Tamub. References to a place called Pambilil, in the East where the forefathers originated, point to a relationship between this document and still another lost Tamub document cited in Fuentes y Guzmán (193233: $7: 388$ ).

There appears to be little new information in Tamub III. The few boundary names listed point to the same zone in the eastern part of Totonicapan which is outlined in Tamub $I$. Velasco apparently lived on the border next to the Ilocab Quiche, with whom he engaged in trade $(k a j a j)$.

\section{T't̂́tulo Ilocab}

This small, 11 page document, was written in 1592 by Juan $\AA$ l. varez, the "chief" (utzam) of the Ilocab division at Totonicapan. On the last page of the document there is a tiny drawing of a building similar to the four Big Houses portrayed in the Titulo Totonicapán pictorial. We are told that it is Alvarez" "palace".

The text is based almost entirely on the Titulo Totonicapán, and consists mainly of a highly abbreviated version of the Old Testament 
account in that document. The "palace" drawing is also based on the Totonicapan pictorial. The only new information is a list of the names of the six founding fathers of the Ilocab lineages. They are said to have come from Tulan with the other "thirteen" groups. The' title of what appears to be the leading prehispanic Ilocab official is given as Rokche K'alel (see also Carmack, 1973: 243-344).

\section{Conclusions}

The Yax of Totonicapan are descendants of the prehispanic rulers of that area, who in turn derived from the royal lines of Utatlan. Since the conquest, they have guarded the indigenous patrimony, including valuable native land titles and chronicles written in Quiche during the 16th century. Through their collaboration, it has been possible to locate and make copies of six Quiche documents, and to begin their translation and analysis. Included among those documents are the original Quiche text of the Title of the Lord's of Totonlicapan, the Yax's own 16th century land title, three early Tamub 'Títulos, and a small 16 th century Ilocab document. These have all been briefly described and evaluated.

It has been argued that work with the native chronicles of highland Guatemala can be productively combined with archaeological research. The documents facilitate the discovery of important Quichean sites, and aid in the interpretation of those sites. The Utatlan pictorial, found attached to the Titulo Totonicapán, is a case illustrating this. Likewise, archaeological studies can lead to the discovery of important native documents, as was true in the present instance. Archaeology can also greatly clarify aspects of native culture mentioned vaguely or not at all in the documents. The fortified outer defenses of Sija and Tzibachaj, called c'oxtun in the documents, illustrate this point.

Even though some of the information contained in the 6 documents from Totonicapan was already available to scholars through other sources, they are an extremely valuable addition to the corpus of Quichean chronicles. Surely they represent a scholarly addition without parallel in Quichean studies since Recinos' publication of Crónicas Indigenas almost 20 years ago. They also once again prove that Mesoamerican ethnohistory can be high adventure. 


\section{Acknowledgements}

The author wishes to acknowledge the financial aid of the National Endowment for the Humanities, and the Research Foundation of the State University of New York in conducting the research leading to the discovery described in this essay. The full cooperation of the Instituto Nacional de Antropología e Historia de Guatemala is also gratefully acknowledged, especially the kind encouragement of its director, Luis Luján Muñoz. Finally, I want to thank the students who worked with me during the Summer of 1973, and my wife who was present at the time we stumbled onto the lead that eventually resulted in finding the documents.

\section{REFERENCES CITED}

CARMACK, R. M.

1966 "La perpetuación del clan patrilineal en Totonicapán". Antropología e Historia de Guatemala, Vol. 18, No. 2.

1968 "Toltec Influence on the Post-Classic culture History of Highland Guatemala". Middle American Research Institute, Tulane University, Publ., 26.

1973 Quichean Civilization: The Ethnohistoria, Ethnographic and Archaeological Sources, Univ. Calif. Press.

Carmacx, R. M., Fox, J., Stewart, R.

1975 La formación del reino Quiché (según la etnología y arqueología). Antropología e Historia de Guatemala.

Carmack, R. M., Larmer, L.

1971 "Quichean Art: A Mixteca-Puebla Variant". Katunob, Vol. 7, No. 3.

Fox, J.

1978 Quiche Conquest. Univ. New Mexico Press, Albuquerque.

Fuentes Y Guzmán, F. A. DE

1932-33 Recordación florida, Guatemala. Biblioteca "Goathemala", Vols. 6-8.

García Elgueta, M.

1962 "Descripción geográfica del departamento de Totonicapán". Guatemala Indígena, Vol. 2, No. 4.

Guillemin, J.

1963 Iximche, Capital del Antiguo Reino Cakchiquel. Antropología e

Las Casas, B. Historia de Guatemala.

1958 Apologética historia de las Indias, 2 Vols. Biblioteca de Autores Españoles, No. 105, Madrid.

MARQuSee, S.

1974 "Mixteca-Puebla trade and styles in Guatemala". Paper delivered at the XLI IVA meetings in Mexico. 
Nicholson, H. B.

1957 Topiltzin Quetzalcoatl of Tollan: A Problem of Mesoamerican Ethnohistory. Dissertation, Harvard University.

Recinos, A.

1950 Memorial de Solola: Anales de los Cakchiqueles. Titulo de los Señores de Totonicapán. Fondo de Cultura Económica, México.

1953 Popol Vuh: las antiguas historias del Quiché. Fondo de Cultura Económica, México.

1957 Crónicas Indígenas de Guatemala. Editorial Universitaria, Guatemala.

Thompson, J. E. S.

1970 Maya History and Religion. University Oklahoma Press.

VILlacorta, C. A. J.

1934 Memorial de Tecpan-Atitlán. Tipografía Nacional, Guatemala. 